\title{
Batik Motif Parang Dari Court Art Menuju Global Trend
}

\author{
Rizki Kurniawan \\ Fakultas Industri Kreatif \\ Universitas Trilogi Jakarta
}

\begin{abstract}
Like other cultures, batik has undergone many developments and changes. Batik Parang in particular has experienced it many times in different periods with a very long time span. From this period, we can see that batik parang have also experienced some ups and downs conditions, which not only caused by outside influences, but also can be caused by various influences from within his own culture. In a due process of change will produce a wide range of output that inevitably will influence directly a form of culture. These conditions also experienced by batik, especially batik parang in the process of developing and adapting to changes. As in batik parang, which evolved from court art, must be degraded into folk art. Batik in order to survive as a cultural form, should be able to adapt changes and sacrificed by decreasing its symbolic meanings to continued its existence in the future.
\end{abstract}

Keywords: changes, influences, adapt, evolved

\section{PENDAHULUAN}

"Tempus mutantur, et nos mutantur in illid". "Waktu berubah dan kita (ikut) berubah juga di dalamnya". Demikian pepatah latin kuno yang mungkin masih ditemukan aktualitasnya sampai sekarang. Begitu juga bila melihatnya dalam konteks kebudayaan, di mana sebuah produk kebudayaan akan selalu berkembang seiring dengan perkembangan jamannya, tidak terkecuali batik. Batik sebagai produk budaya tidak hanya berkembang secara kuantitas dan banyaknya kreasi baru yang terjadi secara fisiknya saja, tetapi juga telah berkembang dengan sedemikian luasnya di berbagai bidang termasuk dalam perkembangan sistem nilai, makna, simbol yang telah menghasilkan pergeseran-pergeseran dari awal penciptaannya. Begitu pula bila dilihat dari segi fungsinya, batik telah banyak mengalami perubahan yang cukup berarti. Pada awalnya batik hanyalah sebuah barang untuk sekedar memenuhi kebutuhan sandang masyarakat, tetapi pada perkembangan selanjutnya dengan banyanya kreasi yang ada menjadikan fungsi batik juga turut berkembang seiring perkembangan jaman dan berbagai fenomena yang menyertainya.

Batik adalah fenomena kultural yang menakjubkan dan telah menjadi tonggak legendaris di bidang penciptaan budaya kain. Selama berabad-abad kehadirannya dalam pelataran budaya bangsa pesona batik telah memperoleh pengakuan dari 
berbagai pihak khususnya pengguna, pencinta kain, pengamat budaya serta cendekiawan dari bermacam cabang keilmuan. Daya tarik batik juga melahirkan kelompok kolektor baik yang pribadi maupun melembaga. Sejumlah besar museum di luar negeri menyimpan produk-produk batik dari mutu yang mungkin terbaik yang pernah dibuat sepanjang sejarah perbatikan di Indonesia belum terhitung yang berada di tangan para kolektor pribadi. Masyarakat pencinta batik di Indonesia di tengah berbagai kendala terus berupaya mengumpulkan bahkan sering membuat ulang karya-karya batik ternama masa lalu.

Gairah apresiasi seperti itu senantiasa perlu dukungan terlebih di tengahtengah pergolakan serta pergeseran nilai yang menyertai gerak dinamis masyarakat yang sedang membangun. Sehingga mampu menjamin pelestariannya sebagai salah satu bentuk perwujudan nilai-nilai luhur budaya bangsa.

Sejarah menunjukan bahwa keberlangsungan batik sampai masa kini juga adalah berkat pergolakan yang senantiasa terjadi dalam berbagai aspeknya apakah itu teknis, estetis, normatif, ikonografis, simbolis, fungsional dan sebagainya. Selama kurun kurang lebih 350 tahun batik telah memaparkan hal itu melalui keterkaitan erat dengan peri kehidupan sosial kultural masyarakat pendukungnya. Kain-kain batik seolah bertutur tentang gejolak riwayat para penyungging, pencelup, penjaja, pembuat canting dan cap, penyedia bahan kain dan pewarna, pengusaha, dan kiprah perilaku selera konsumen dalam bauran kehidupan masyarakat serta lingkungannya. Dialektika dalam kehadiran batik mengungkapkan hasrat serta upaya untuk senantiasa tanggap terhadap perubahan.

Batik sebagai sebuah artefak seni Nusantara merupakan implementasi dan ekspresi kebudayaan dari kehidupan masyarakatnya dengan latar belakang pemikiran, filsafat, alam dan lain sebagainya. Yang kemudian berkembang secara luas tidak hanya dipandang hanya sebagai wujud kebudayaan yang bersifat bendawi saja tetapi lebih kepada pengertian makna, nilai dan simbolnya. Dari sinilah baru dapat ditarik perbedaan yang khas antara batik yang hanya sebagai teknik rintang warna belaka yang mungkin ada di hampir semua kebudayaan dunia dengan batik yang berkembang di Indonesia khususnya Jawa yang merupakan perwujudan kebudayaan yang sarat akan makna, nilai dan simbol yang tidak akan ditemui pada kebudayaan lainnya.

Perkembangan Batik dari sebuah komoditas pertukaran dan perdagangan antar negara serta berkembang luas pada masyarakat umum khususnya saudagar pada awal perkembangannya dan dikenal sebagai Batik rakyat. Telah ditarik kedalam lingkungan istana yang lebih terbatas dan disakralkan pemakaiannya di mana Batik diberikan tempat yang 
tinggi derajatnya sehingga terciptalah motif-motif larangan yang hanya boleh dipakai oleh kerabat keraton saja.

Adanya motif-motif larangan tersebut selain juga sebagai alat atau simbol untuk membedakan antara bangsawan dan rakyat biasa, tetapi juga sebagai pembuktikan adanya sentuhan halus dari tangan kaum bangsawan berhasil mengidentifikasikan karya tersebut sebagai produk keraton yang mencerminkan idealisasi budaya Jawa sebagai sebuah budaya kehalusan budi. Bila dilihat perkembangan Batik secara garis besar maka dapat dikatakan bahwa kedudukan batik pada masyarakat di indonesia khususnya Jawa bisa menjadi gambaran di mana perubahan budaya menjadi sebuah proses dialog yang terus menerus dan membuat kebudayaan terus berkembang. Dialog yang terjadi di akhir abad 19 membangun sistem nilai di pelbagai bidang kehidupan baik politik, pola pikir, ekonomi, gaya hidup, pendidikan hingga adat istiadat. Hal ini dapat dilihat dari pergeseran batik yang tadinya hanya menjadi "cour art" yang sangat sakral dan berlandaskan etika serta dasar filosofis yang tinggi dan hanya beredar dalam lingkungan keraton saja, tetapi karena adanya tuntutan zaman dan adanya keterbukaan pemikiran akibat dari pendidikan barat serta kebutuhan ekonomi menyeret batik kembali menjadi "folk art" yang sangat profan sehingga dapat dinikmati oleh segala kalangan.

Proses ini juga berkaitan dengan adanya pemikiran dimana fenomena pembebasan kelas dan anti feodalisme yang berkembang di masyarakat pada saat itu. Serta peran pengrajin dalam menguasai proses pembuatan batik dari penulisan sampai menjadi kain yang siap pakai serta peran bangsawan keraton yang menghendaki ketersediaan kain untuk keperluann mereka ikut membuat batik menjadi kehilangan keeklusifannya karena telah diproduksi diluar tembok keraton.

Sampai pada akhirnya batik menjadi salah satu bagian dari budaya populer yang terjebak pada kesementaraan, memaksa batik terdegradasi dari sebuah simbol tradisi menjadi sekedar ragam hias pelengkap budaya. Di sini bisa dicermati bahwa setelah adanya pergeseran dari proses pembebasan kelas menjadi pembebasan nilai secara sadar atau tidak sadar telah membiarkan budaya menjadi terkikis.

Perubahan kebudayaan tersebut menghasilkan efek domino yang berdampak luas di semua aspek kehidupan. Walaupun banyak sekali perubahan dan perkembangan jaman yang terjadi, seni batik tetap merupakan lambang tingginya suatu citra budaya suatu bangsa. Pengaruh sistem nilai tadisi yang telah ada seperti Folklore dan mitos yang berkembang di masyarakat menjadi satu-satunya alat untuk menjaga dan menjadi garda terakhir kebudayaan dimasyarakat.

Dalam sebuah kebudayaan, perubahan-perubahan dan fenomenafenomena yang menyertainya adalah suatu hal yang lazim. Perjalanan batik dari "cour art" yang sakral menjadi 
"folk art" yang profan (bersahaja) menuju "global trend" yang kontemporer juga tidak luput dari fenomena yang menyertainya. Adanya perubahan tersebut juga mengakibatkan perkembangan dan pergeseran terhadap sistem nilai, makna dan simbol pada batik khususnya batik klasik yang pada awal mulanya berkembang di lingkungan kraton. Dalam perkembangan batik, fenomena yang menyertainya tidaklah sebatas pada fenomena yang berhubungan dengan kesenian dan kebudayaan saja, tetapi juga banyak terpengaruh oleh perkembangan jaman yang ada termasuk di dalamnya dipengaruhi oleh fenomena-fenomena di berbagai bidang antara lain: ekonomi, politik, sosial, dan lain sebagainya. Fenomena-fenomena tersebut sangat banyak mempengaruhi batik dalam berbagai hal, mulai dari segi desain sampai pada keberadaan batik dari awal penciptaannya hingga sekarang. Selain mempengaruhi batik secara langsung, perkembangan yang disertai fenomena-fenomena tersebut juga berpengaruh pada masyarakat penggunanya mulai dari masyarakat di lingkungan kraton yang melihat dari sudut pandang tradisi yang kental hingga masyarakat luas yang melihat batik dari berbagai sudut pandang.

Seiring perkembangan jaman ternyata telah membawa batik terbebas dari ikatan kesakralan tradisi keraton yang kental dan membaur dan berpadu dengan motif-motif rakyat kebanyakan dan membentuk motif baru yang semakin meragamkan motif batik pada masa selanjutnya. Adanya proses perubahan tersebut kiranya yang menarik untuk diteliti dengan melihat sejauh mana perubahan yang terjadi. Dari satu proses yang melegitimasikan motif tersebut hanya sebagai motif Sultan hingga ditariknya kembali kesakralan motif tersebut keluar tembok istana dan menjadi profan serta dapat dilihatnya bagaimana interaksi dan adaptasi motif tersebut dengan perkembangan jaman selanjutnya.

\section{METODE PENELITIAN}

Penelitian ini secara umum adalah penelitian kualitatif dibidang desain khususnya perkembangan batik motif parang dengan menggunakan pendekatan transformasi budaya. Pada pendekatan transformasi kebudayaan, dalam pelaksanaannya banyak didukung oleh disiplin ilmu-ilmu lain, baik disiplin ilmu yang berhubungan serta berkaitan langsung dengan bidang desain maupun juga disiplin ilmu lain yang secara tidak langsung tetapi ikut mempengaruhi desain dari sudut pandang tertentu. Serta adanya upaya untuk memahami permasalahan yang ditemukan dengan menggunakan teori-teori yang berlaku dan berusaha mengiterpretasikannya dengan temuan-temuan yang ada, maka analisis yang diambil adalah analisis Interpretatif. Di mana pada analisis ini dilakukan interpretasi atas apa yang telah dilakukan oleh pribadi atau kelompok manusia terhadap situasi mereka sendiri. Setiap peristiwa atau karya memiliki makna dari interpretasi para pelaku atau pembuatnya. Karya yang merupakan hasil interpretasi tersebut selanjutnya menghadapi 
pembaca atau pengamat dan ditangkap dengan interpretasi pula.

\section{BATASAN MASALAH}

Dalam hal ini batasan dan ruang lingkup objek penelitian adalah pada perubahan yang terjadi pada batik di Indonesia khususnya batik motif parang, dengan melihat dari awal mulanya motif larangan ini berkembang di lingkungan keraton Mataram. Yang pada akhirnya motif parang ini dapat menjadi motif yang biasa dan dipakai oleh orang kebanyakan serta dapat berpadu dengan motif lain untuk menambah keberagaman motif yang ada. Pada perkembangan selanjutnya, motif parang ini ingin dibawa dan diupayakan oleh beberapa agen perubahan ke lingkungan yang lebih luas lagi yaitu lingkungan global sebagai motif yang menjadi identitas Indonesia.

\section{HASIL DAN ANALISIS}

\section{Motif Batik Parang Dan Proses Perubahannya}

Parang adalah karang yang tajam atau sebuah golok yaitu senjata tajam yang lebih besar dari pisau atau lebih kecil dari pedang. Dalam penampilannya, motif parang sering diilhami oleh golok, keris, dan teratai yang diatur secara rapi dan teratur berulang-ulang.

Sudah lama para ilmuwan berselisih pendapat tentang makna kata parang. Kebanyakan berpendapat bahwa artinya adalah pedang atau pisau. Kebetulan memang penampilan desain parang itu mirip dengan pedang dan pisau. Jika dapat diperhatikan pola parang maka orang akan berfikir bahwa desain itu ditentukan oleh aluralur miring yang panjang. Sebenarnya alur itu adalah deretan belah ketupat gelap atau biasa disebut mlinjon, yang tertanam dalam persilanganpersilangan desain.

Jenis motif parang yang sangat terkenal adalah motif parang rusak. Motif parang rusak adalah motif yang sangat digemari oleh raja dan para bangsawan, sehingga di dalam lingkungan kraton motif ini menjadi motif larangan yang hanya boleh dipakai oleh raja dan kerabat dekatnya saja. Menurut kepercayaan kejawen, parang rusak dianggap mempunyai kekuatan kepada siapa yang memakainya untuk maju ke medan perang dengan maksud supaya bisa merusak atau menghancurkan perlawanan musuh.

Lebih lanjut, parang rusak adalah sumber kehidupan (keselamatan), karena motif parang rusak mempunyai tenaga penghalang terhadap semua kerusakan (kematian). Sedangkan lebih lanjut Parang rusak menurut Suryanto Sastroatmodjo (1993), mempunyai kekuatan untuk menangkis mara bahaya, musibah, dan bencana alam. Motif ini menjadi keramat di dalam lingkungan kraton yang melambangkan kehidupan, yaitu Sang Pencipta Alam Semesta. Untuk itulah parang rusak dikhususkan hanya untuk raja karena dianggap penjelmaan dari Bathara Guru atau Hyang Jagad Girinoto. 

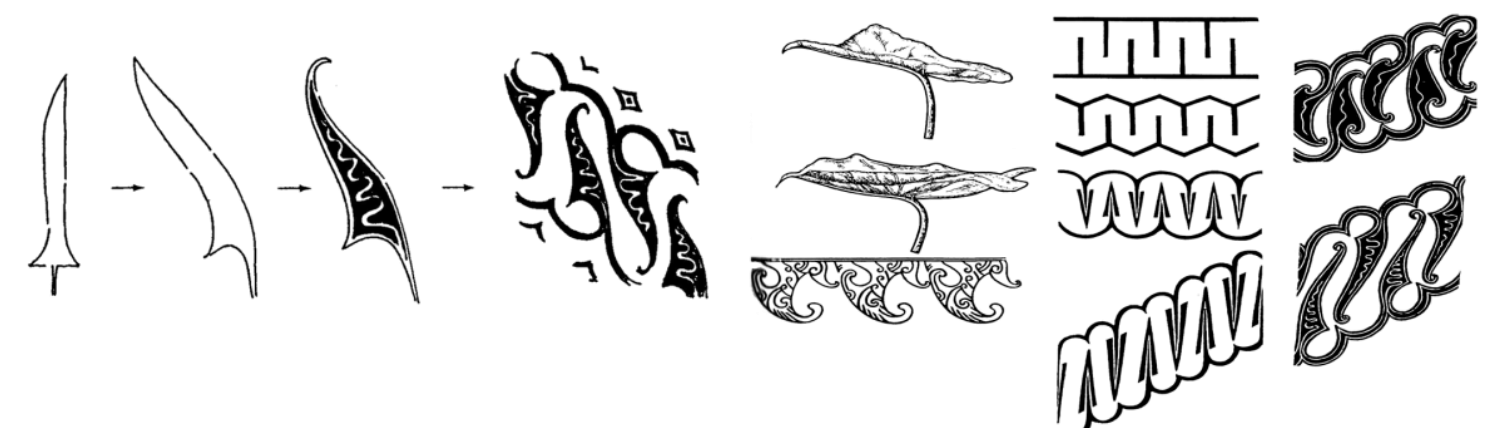

Gambar 1. (Kiri) Perubahan dari bentuk pisau atau parang menjadi motif parang (Kanan) Perubahan dari bentuk daun teratai dan meander menjadi motif parang (sumber: Repro-Scan Drs. Aryo Sunaryo, 2009)

Pada intinya motif parang rusak hanya boleh dipakai oleh raja, keluarga raja, dan kerabat raja karena dianggap sebagai jelmaan dari Yang Maha Kuasa yang dapat melindungi di manapun berada dan sebagai simbol kebangsaan. Dan semua tugas itu adalah tugas seorang raja sebagai perwakilan Tuhan di muka bumi dalam menjalankan tugas kenegaraan supaya diberi kekuatan, keteguhan, dan keselamatan.

Seniman batik yang telah lanjut usia akan mengatakan bahwa tanpa mlinjon, maka motif batik tersebut bukanlah parang melainkan desain diagonal biasa saja yang lazim digolongkan sebagai pola lereng atau garis miring belaka. Mlinjon dengan bentuk belah ketupat itulah yang menentukan desain tersebut motif parang atau bukan. Mlinjon itu bahkan dapat disejajarkan dengan latar (ruang) berbentuk belah ketupat di tengah kain upacara berukuran besar yang disebut sebagai kampuh. Ruang kosong yang berbentuk belah ketupat pada kampuh ini dinamakan bangun tulak, yang artinya kira-kira 'menolak yang jahat'. Sehingga dapat dikatakan mlinjon adalah pelengkap dan penguat dari makna motif parang.

Batik motif parang pada awalnya adalah motif yang dikeramatkan dan hanya diperuntukan bagi Sultan Yogyakarta saja dan dilarang dipakai oleh siapapun selain Sultan. Pelarangan ini dikemudian hari juga diikuti oleh motif-motif lain seperti sawat lar, cumengkringan dan udan liris (Dharsono, 2007, 42).

Adanya bermacam-macam motif kain larangan itu tidak dimaksudkan hanya untuk membuat variasi dalam cara pemakaian seperti halnya yang terjadi pada jaman sekarang. Tetapi tiap-tiap desain motif tersebut mempunyai arti khusus dan dari cara memakainya bisa memperlihatkan kedudukan pemakainya. Tidak hanya itu saja motif-motif ini juga hanya dipakai untuk upacara-upacara tertentu saja seperti pada upacara pelamaran, pertunangan atau perkawinan.

Kembali kepada adanya motif-motif larangan yang berkembang pada lingkungan keraton di Jawa khususnya 
di Yogyakarta. Motif-motif tersebut mendapatkan legitimasinya di mata rakyat kebanyakan sebagai batik aristokrat yang sebenarnya pada awal mulanya adalah ekspresi kebudayaan rakyat biasa yang naik derajatnya, dalam hal ini dapat dicermati pada kasus yang akan diangkat yaitu perkembangan dan dinamika Batik motif Parang.

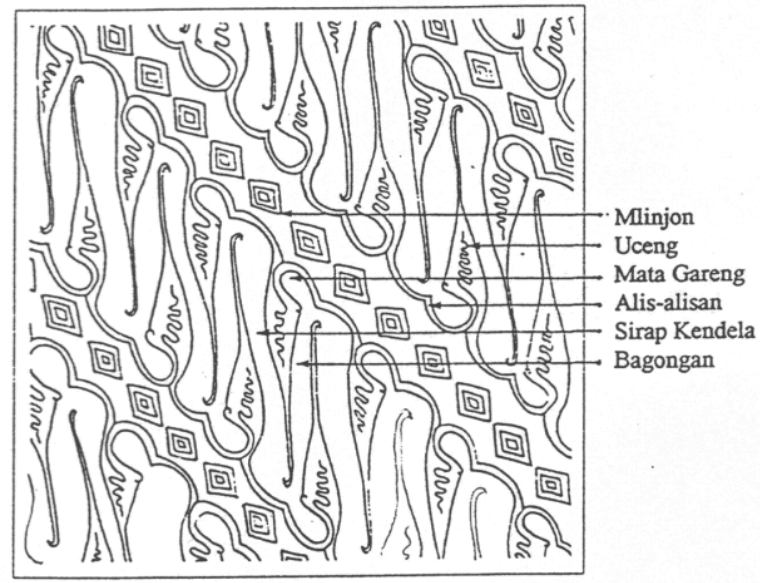

Gambar 2. Motif Parang (sumber : ReproScan Yayasan Harapan Kita, 1999).

Bila melihat dari desain Batik dewasa ini maka motif Parang telah berubah dari sebuah motif yang bernilai sakral menjadi motif yang sangat profan. Ini bisa diamati dengan adanya perpaduan motif parang ini dengan motif-motif pesisiran yang merupakan motif-motif batik rakyat kebanyakan. Sehingga nilai kesakralan motif ini menjadi terdegradasi menjadi batik biasa dan dapat dipakai oleh siapa saja. Perbedaan antara batik klasik dan batik jaman sekarang hanya dapat dilihat melalui tata cara dan pemahaman pemakainya akan tradisinya dan cara memakainya.
Perubahan-perubahan ini tidak dapat terjadi begitu saja atau terjadi dengan sendirinya. Perubahan ini dapat terjadi karena adanya berbagai macam peristiwa yang menyertainya atau juga karena adanya agen-agen perubahan yaitu seniman dan pengrajin batik yang ingin memperbaharui batik ke arah yang lebih baik. Pembaharuan ini berkembang pesat khususnya pada era setelah kemerdekaan Indonesia (Fred W. Van Oss, 1996, 40).

Pada masa kini, kain-kain batik bermotif khas keraton sudah umum dibuat oleh pengusaha-pengusaha batik dan dengan kemajuan teknologi tekstil yang berkembang di dunia juga menjadikan batik menjadi terjangkau harganya oleh masyarakat kebanyakan. Akibatnya makin banyak motif batik yang dahulu merupakan motif larangan dengan dikombinasikan dengan teknik baru antara lain cap dan cetak sehingga proses produksinya jadi semakin mudah dan ongkosnya juga semakin murah dan ini menjadikan batik-batik motif tersebut dapat menjadi konsumsi orang kebanyakan.

Pemakaiannya sebagai busana merupakan salah satu sisi terpenting dalam dunia batik, karena batik memiliki lambang yang mencerminkan derajad sosial dan kebanggan si pemakai (Wastraprema, 1990, 37). Penggunaan batik sebagai sebuah pakaian atau kain penutup juga telah jauh berubah, dari yang tadinya hanya sebagai kain penutup dan pelengkap pakaian saja, melainkan sekarang telah bertransformasi pula menjadi sebuah 
busana. Di mana kain panjang yang tadinya hanya sebagai penutup telah berubah menjadi pakaian resmi yang mengambil desain busana barat. Ini juga telah menunujukan kepada kita bahwa dinamika dan perubahan batik khususnya motif parang telah sedemikian rupa berubah dengan mengikuti perkembangan jamannya.

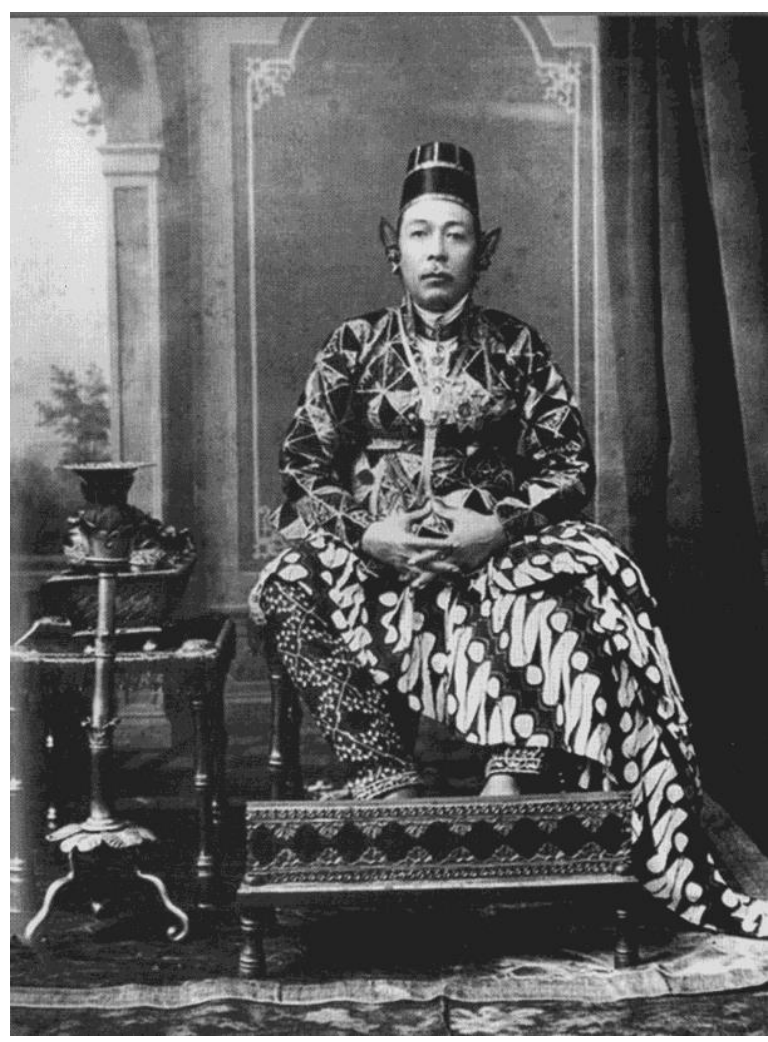

Gambar 3. Sultan PB VII memakai busana keprabon motif batik parang barong (sumber : Repro-Scan Mari Condronegoro, 2010)

Kehidupan batik di Indonesia memiliki perjalanan yang sangat panjang, apabila dilihat dari aspek kegunaannya sebagai piranti magis yang menyertai berbagai ritual, sebagai pakaian yang mampu menunjukkan strata sosial pemakainya, sebagai barang yang mempunyai nilai ekonomi tinggi dan juga sebagai salah satu warisan budaya bangsa yang dapat menjadi identitas nasional. Batik telah mengalami perkembangan seiring dengan tuntutan penggunaannya, perkembangan yang terjadi telah pula membuktikan bahwa batik sangat dinamis dan dapat menyesuaikan diri baik dalam dimensi ruang, waktu dan bentuk (Timbul Haryono, 2008, 12).

Batik merupakan citra budaya Indonesia yang memiliki ciri khas karena kerumitan, kerajinan, dan kehalusan ragam hiasnya akibat tapak canting yang dilukiskan. Dan potensi pembatik cukup tersebar luas, menanti uluran tangan perancang atau seniman, untuk berjalan bersama ke masa depan. Jika kita ingin membicarakan tentang kebudayan maka kita tidak dapat terlepas dari kata perubahan karena kebudayaan yang terus berkembang dari masa ke masa sangat identik dengan apa yang disebut perubahan. Begitupula bila kita ingin membicarakan batik sebagai salah satu hasil dari sebuah kebudayaan. Sebagai sebuah hasil dari kebudayaan batik dapat dikatakan merupakan sebuah bentuk dari aktivitas berkesenian yang banyak dipengaruhi oleh aktivitas perekonomian, politik, sosial, teknologi, nilai-nilai filsafat dan nilainilai adat serta keagamaan.

Dalam perkembangannya batik dapat dikatakan telah melalui sebuah perjalanan yang amat panjang, mulai dari sebuah bentuk kesenian atau kriya rakyat kebanyakan yang dipergunakan untuk keperluan pribadi sampai menjadi sebuah kesenian yang agung 


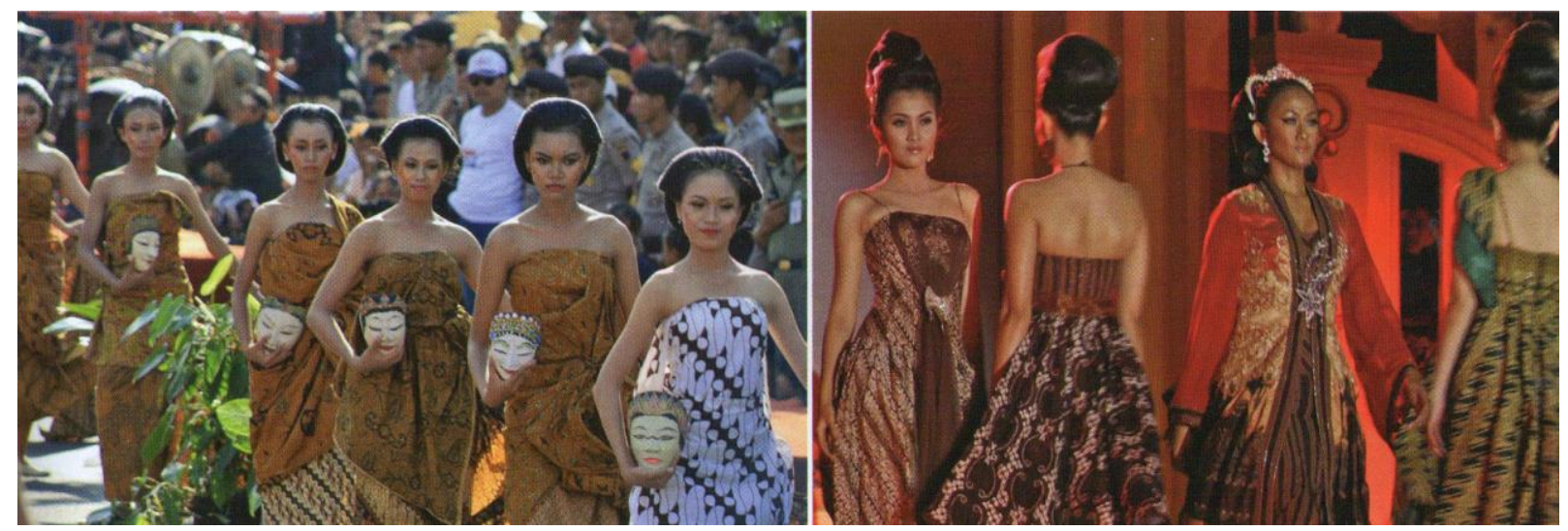

Gambar 4. Festival batik solo dimana ada dua penggunaan batik secara tradisional dan modern (sumber : www.solobatikfestival.com )

ketika dilegitimasi oleh kraton sebagai bagian dari budaya istana Jawa yang sarat akan nilai-nilai simboliknya, hingga menjadi sebuah identitas kebudayaan suatu bangsa seperti sekarang ini. Dapat dikatakan bahwa batik telah mengalami pasang surut perubahan dalam perjalanannya baik yang menggembirakan maupun sebaliknya.

Meskipun batik merupakan sebuah bentuk berkesenian yang mengandung kearifan lokal dan banyak diperlihatkan pada motif-motif klasik yang sarat akan makna simboliknya, tetapi batik harus menerima bahwa perubahan adalah suatu yang tidak dapat dihindarkan. Dari berubahnya bentuk masyarakat yang tadinya terpecah dalam lingkungan-lingkungan berbasis etnisitas yang kental akan adat istiadatnya, kemudian seiring dengan tuntutan jaman harus menerima sebagai sebuah bagian dari bentuk pemerintahan yang lebih besar dengan segala keragaman budayanya, sampai pada kenyataan harus terimbas oleh pengaruh perubahan budaya dunia yang semakin mendunia dan tuntutan untuk tetap positif dalam menyikapinya karena memang tak dapat terhindarkan lagi sebagai bagian dari masyarakat internasional.

Keberadaan batik tidak dapat dilepaskan dengan perkembangan peradaban manusia khususnya kebutuhan akan sandang atau berpakaian. Batik yang pada awalnya sebagai pemenuhan akan sandang yaitu sebagai pakaian sehari-hari oleh rakyat kebanyakan. Kemudian dengan terbentuknya Kerajaan-kerajaan Islam di Jawa khususnya pasca Majapahit telah membawa batik kedalam tingkatan lebih lanjut dengan dilegitamasikannya batik sebagai budaya dan kesenian istana di mana ada beberapa motif yang hanya diperuntukan bagi kalangan istana saja serta secara tidak lansung sudah 
melakukan pembatasan-pembatasan dalam peruntukannya sebagai busana.

Pada tahap selanjutnya, dengan memudarnya pengaruh istana dan membawa batik ke tataran yang lebih luas yaitu sebagai budaya nasional yang membuat batik dapat dipakai oleh siapa saja serta dapat dipergunakan untuk berbagai keperluan dan tidak lagi hanya terbatas untuk busana upacara adat tertentu saja. Hingga adanya pengaruh globaliasi yang tidak dapat dihindarkan, memaksa batik harus dapat beradaptasi dengan perubahanperubahan yang begitu pesat sesuai trend yang berlaku pada waktu itu, dan hal ini membuat pemakaian batik semakin luas dengan tidak hanya sebagai busana tetapi telah dipergunakan untuk berbagai hal yang bahkan tak terpikirkan sebelumnya.

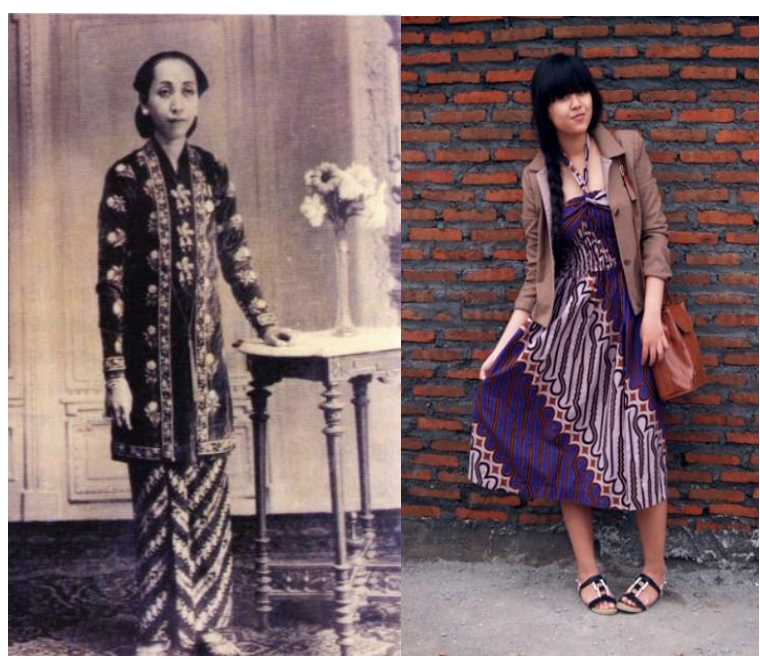

Gambar 5. Contoh penggunan batik motif parang dengan gaya tradisional dan busana modern pengaruh barat. (sumber : Repro-Scan Mari Condronegoro, 2010 dan www.webgaul.com ) secara tradisional dan modern (sumber : www.solobatikfestival.com )
Dengan adanya pengaruh globalisasi ini batik juga harus menerima kenyataan bahwa makna-makna simbolik yang terkandung dalam berbagai motif klasiknya harus sedikit demi sedikit tergerus oleh berbagai kepentingan hingga hanya menjadi sebuah ragam hias semata.

\section{Batik Dan Upaya dalam Menjawab Tantangan Jaman}

Pada periode selanjutnya, perkembangan batik senantiasa mengikuti perkembangan situasi politik, ekonomi dan sosial Indonesia pada umumnya. Memasuki masa setelah Revolusi tahun 1965, situasi perekonomian dan politik Indonesia lambat laun mulai membaik. Pembangunan yang dicanangkan oleh pemerintah telah berkembang di semua bidang dan segi kehidupan masyarakat, dengan berasaskan keadilan sosial. Dengan dibukanya peluang impor yang tidak lagi dimonopoli dan didominasi oleh organisasi serta badan usaha bentukan pemerintah saja, perubahan kondisi usaha niaga ini merupakan titik balik kondisi ekonomi dari periode sebelumnya. Hal ini tidak hanya berpengaruh pada perekonomiaan Indonesia secara keseluruhan tetapi juga berpengaruh langsung pada usaha produksi batik pada khususnya.

Dengan dibukanya pintu impor yang seluas-luasnya mengakibatkan fungsi koperasi dalam hal ini koperasi batik GKBI telah tidak lagi terlalu berperan. Keadaan ini dimanfaatkan oleh para pengusaha batik untuk mengadakan bahan baku dengan cara mengimpor 
sendiri secara langsung sehingga harga bahan baku dapat ditekan semurahmurahnya, ini mengakibatkan semangat industri batik bangkit kembali setelah sempat lesu dikarenakan harga bahan baku yang tidak terjangkau. Dengan ketersediaannya bahan baku murah dan mudah didapat membuat para pengusaha batik baik yang berskala kecil maupun besar menggairahkan kembali untuk meningkatkan produksinya.
Pada masa ini pula berkembang batik dengan teknik cap yang dapat meningkatkan produksi batik menjadi lebih besar. Teknik cap dipilih karena dengan teknik ini batik yang dihasilkan dapat dijual dengan murah karena proses produksinya yang lebih sederhana dibandingkan teknik tulis. Tetapi dengan adanya teknik cap ini tidak serta merta membuat produksi batik tulis ditinggalkan oleh para perajin dan pengusaha tersebut. Batik tulis masih terus diproduksi walaupun

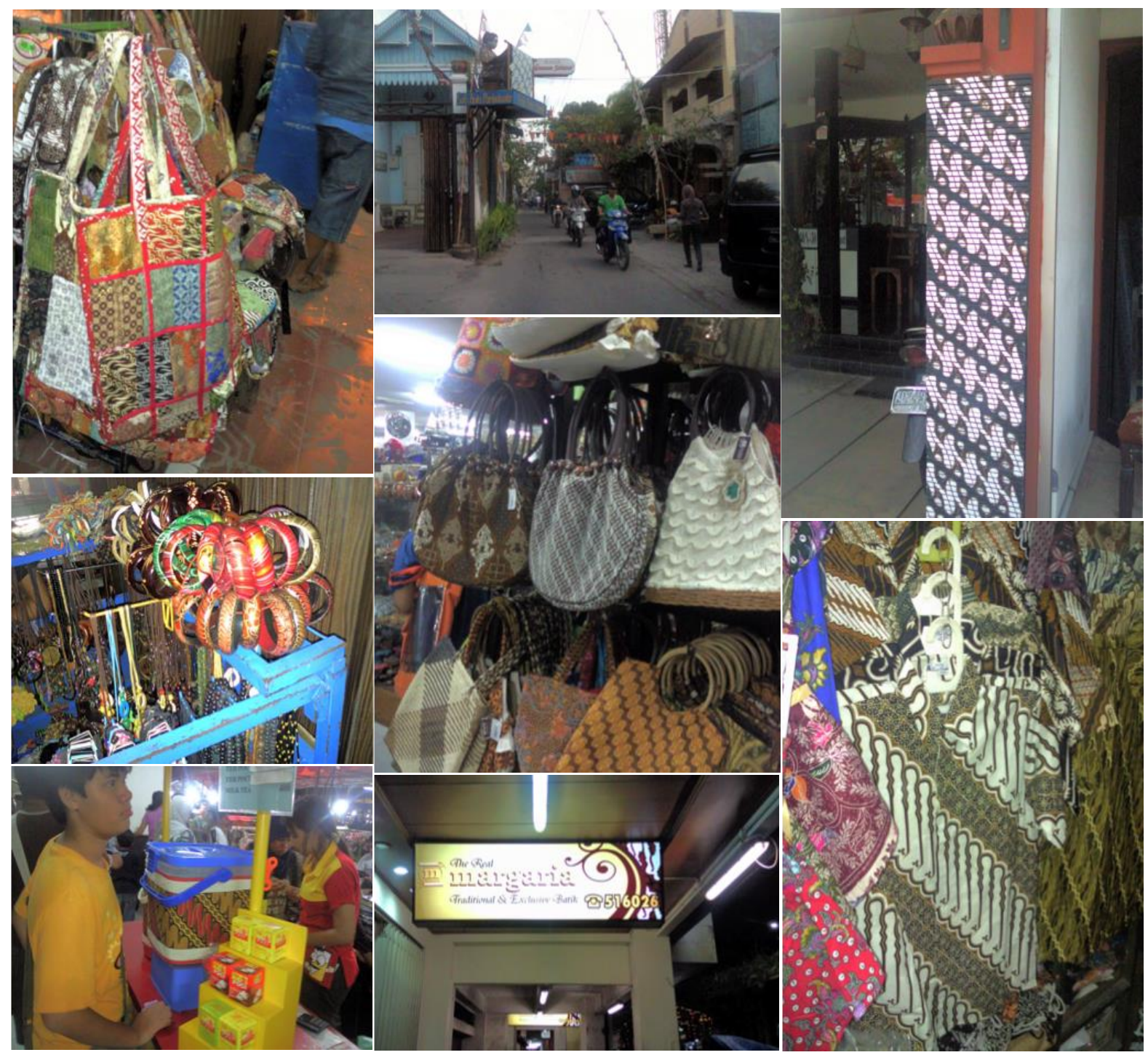

Gambar 6. Contoh pemakaian batik khususnya motif parang dalam beragam kegunaan pada masa sekarang (sumber : foto Rizki Kurniawan, 2010) 
jumlahnya dibuat secara terbatas dan hanya untuk memenuhi pesanan khusus, dikarenakan eksklusifitasnya dan kerumitan proses produksinya maka batik ini dihargai dengan harga yang tinggi, lebih mahal daripada batik dengan teknik cap.

Pada perkembangan selanjutnya dengan melihat makin maraknya penggunaan batik di berbagai segi kehidupan, yang tidak lagi terbatas pada penggunaannya sebagai busana, pelengkap busana dan kain, tetapi telah meluasnya pemakaian batik hingga menjadi berbagai bentuk barang, dari perlengkapan interior, perlengkapan makan sampai pada produk kerajinan berbahan dasar bukan kain (kayu), maka semakin banyak dari kalangan pengusaha yang melihat peluang yang sangat terbuka untuk memenuhi kekosongan permintaan terhadap produk-produk batik tersebut.

Salah satu usaha memanfaatkan peluang tersebut adalah dengan membuat kain bermotif batik yang dapat diproduksi dengan cepat dan banyak guna memenuhi kebutuhan pasar terebut, maka berkembanglah penggunaan tekstil yang bermotif batik dengan menggunakan teknik sablon dan printing yang dapat menghasilkan berpuluh-puluh hingga ratusan meter kain bermotif batik dengan waktu yang singkat. Semenjak adanya kemajuan teknologi yang berkembang saat itu membuat batik tidak lagi diartikan menjadi suatu karya kriya yang membutuhkan proses dan ketrampilan khusus dalam memproduksinya, tetapi telah beralih sepenuhya menjadi sebuah komoditas yang tak lagi perduli akan proses pembuatannya yang banyak mengandung nilai luhur dan pada akhirnya hanya menjadi sebuah ragam hias atau sebuah motif diatas tekstil yang tidak bermakna serta hanya dilihat dari segi komersialnya saja. Inilah yang mendorong para pengusaha batik yang pada awalnya memproduksi kain secara tradisional, pada akhirnya kemudian beralih hanya menjadi pengumpul batik dari para pengrajin lalu menjualnya dipasarpasar.

\section{KESIMPULAN}

Seperti telah diketahui, maka dapat dikatakan bahwa batik merupakan salah satu warisan budaya Indonesia yang sangat penting dalam perkembangan budaya secara umum serta khususnya dalam perkembangan berbusana. Sebagai salah satu warisan budaya terpenting, batik telah melampaui berbagai macam dinamika dan perubahan seiring jaman yang menyertainya, dari masa-masa yang sulit hingga dapat bertahan sampai saat ini.

Walaupun batik telah diakui secara nasional dan internasional sebagai sebuah warisan budaya yang sangat penting dalam perkembangan budaya Indonesia, banyaknya pengaruh luar atau asing yang mempengaruhinya dalam proses dan teknik pengerjaannya serta mempengaruhi perkembangan desain motif yang sangat beragam sehingga batik dapat 
bertahan sampai sekarang berkat kedinamisannya beradaptasi.

Pada awalnya batik adalah sebuah produk kerajinan yang dikerjakan secara halus oleh para perajin dengan berbagai macam atribut serta ritual yang menyertai proses pembuatannya. Pada pembuatannya batik banyak mengandung makna-makna kehidupan yang begitu luhur yang diimplementasikan pada motif-motif yang dibuat serta bagaimana cara batik itu dikenakan. Pada tahap selanjutnya, dengan semakin berkembangnya jaman batik tidak lagi dilihat sebagai sebuah produk yang agung di mana segala atribut dan ritual serta maknamakna yang terkandung di dalamnya menjadi tidak penting lagi. Batik telah lebih banyak dipengaruhi oleh faktor ekonomi yang hanya mengejar kwantitas produksi dan keuntungan belaka dengan mengesampingkan segala esensi dasar batik yang penuh dengan makna tersebut.

Batik pada akhirnya dilihat hanya sebagai ragam hias yang dinilai secara estetis, tetapi sudah tidak lagi dimengerti secara filosofisnya bahkan terjebak pada perkembangan gaya hidup serta trend fashion yang ada pada saat ini. Batik pada tahap selanjutnya lebih mengacu pada ekspresi seseorang atau perajin secara personal sehingga dapat berkembang secara lebih bebas. Orang tidak lagi perduli bagaimana batik itu dibuat dengan segala proses yang sarat akan makna yang menyertainya ataupun bagaimana sebuah motif mempunyai makna filosofis yang mengacu pada falsafah kehidupan, tetapi hanya melihat bagus tidaknya serta dapat mengikuti tren.

Tetapi kenyataan ini juga tidak dapat dilihat sepenuhnya secara negatif, karena dengan adanya perkembangan batik seperti sekarang ini justru telah membangkitkan batik dari mati surinya selama ini. Dengan adanya kesadaran banyaknya orang memakai batik akhirakhir ini telah menumbuhkan gairah hidup industri batik yang pada akhirnya juga ikut mendorong semakin berkembangannya kreativitas para perajin dalam mengembangkan batik tidak hanya sebagai busana saja tetapi telah dapat dimanfaatkan untuk beragam keperluan di berbagai bidang. Sebuah perubahan tidak dapat dihindarkan lagi pada batik, khusus untuk motif parang perubahan yang kentara adalah baik secara fisik maupun non fisiknya, hingga dengan adanya pengaruh sosial politik serta teknologi dan gaya hidup yang membuat motif parang berubah bentuk secara keseluruhan. Secara non fisik motif parang yang tadinya merupakan motif larangan dan hanya diperuntukan bagi sultan serta kerabatnya saja, ternyata pada perkembangannya telah menjelma menjadi sebuah motif yang sangat populer yang sangat digemari oleh masyarakat dan tidak terbatas lagi hanya untuk sultan dan kerabatnya saja. Sehingga makna larangan yang ada pada motif parang justru telah hilang dan tergantikan oleh makna populer dan trend yang berkembang.

Adanya pergeseran nilai ini tidak boleh dilihat secara negatifnya saja, karena 
tuntutan jaman memang tidak dapat dihindari. Tetapi justru dengan adanya pergeseran ini malah dapat memperkaya ragam, warna, dan bentuk batik parang yang ada dan menjadi daya tarik tersendiri pada perkembangan selanjutnya, walaupun telah kehilangan nilai simboliknya, tetapi justru keadaan ini dapat membuat batik tetap lestari sampai sekarang dan masa-masa selanjutnya.

Sebagai sebuah hasil dari sebuah kebudayaan yang bercirikan kearifan lokal, batik diharapkan tidak hanya menjadi sebuah warisan yang hanya dipraktikan dan diturunkan secara turun temurun. untuk dapat bertahan dan beradaptasi dalam sebuah perubahan, batik diharapkan dapat menjadi sebuah kebudayaan yang keberadaannya bergantung pada perubahan yang ada dari waktu kewaktu secara terus menerus dalam sebuah keseluruhan interaksi sosial dan budaya yang ada.

Dengan diakuinya batik sebagai salah satu budaya asli Indonesia dapat menempatkan batik tidak hanya sebagai sebuah simbol identitas kultural Indonesia saja tetapi batik juga dapat menjadi sarana diplomasi kultural Indonesia di pergaulan luas dunia. Ditataran lokal, untuk dapat mengenalkan batik secara proporsional dengan segala pemahamannya kepada masyarakat, perlu adanya sebuah sistem yang terpadu, dimana pengenalan ini dapat diimplementasikan dalam berbagai bidang, khususnya dalam bidang pendidikan.

\section{DAFTAR PUSTAKA}

Barker, Chris

2005. Cultural Studies - Teori dan praktik, Yogyakarta : Bentang

Boow, Justine

1988. Symbol and Status in Javanese Batik,

Australia : University of Western

Australia

Condronegoro, Mari

2010. Memahami Busana Adat Kraton Yogyakarta - Warisan Penuh

Warna, Yogyakarta : Pustaka Nusatama

Dharsono

2007. Budaya Nusantara - Kajian Konsep

Mandala dan Tri Loka/Buana terhadap Pohon Hayat pada Batik

Klasik, Bandung : Rekayasa Sains

Doellah, Santosa

2002. Batik - Pengaruh Zaman dan Lingkungan, Surakarta : Danar Hadi

Geertz, Clifford

1995. Kebudayaan dan Agama, Yogyakarta : Kanisius Haake, Annegret

1984. Javaisch Batik, Hannover : Verlag M \& H Schaper Jasper, J.E \& Pirngadie

1916. De Batikkunst: De Inlandsche Kunst Nijverheid in Nederlandsch Indie, Amsterdam

Lombard, Denys

1996. Nusa Jawa Silang Budaya Warisan-warisan Kerajaan

Konsentris, Jakarta : Gramedia Pustaka Utama

Susanto, Sewan S.K.

1973. Seni Kerajinan Batik Indonesia, Balai Penelitian Batik dan Kerajinan - Departemen Perindustrian RI, Yogyakarta 
Suyanto, A.N.

2002. Sejarah Batik Yogyakarta,

Yogyakarta : Rumah Penerbitan Merapi

Tirta, Iwan.

2009. Batik Sebuah Lakon, Jakarta : Gaya Favorit Press
Wastraprema.

1990. Sekaring Jagad Ngayogyakarta Hadiningrat, Wastraprema Yayasan Harapan Kita

1999. Indonesia Indah - Buku 8, Batik, Jakarta : Yayasan Harapan Kita 